Global Commission for the Certification of Smallpox Eradication, certify that smallpox has been eradicated from the world'. It was on the basis of the evidence provided in the Final Report of the Global Commission,* which is now in the course of publication by WHO, that the World Health Assembly, representing 155 countries of the world, participated in the historic declaration on 8 May 1980.*

*See top footnote on page 173 and the WHO account following it; also footnote on page 177.-Ed.

\author{
Frank Fenner, Chairman \\ Global Commission for the Certification of \\ Smallpox Eradication, World Health Organization; \\ John Curtin School of Medical Research \\ The Australian National University \\ Canberra City, ACT 2601 \\ Australia; \\ formerly Director \\ Centre for Resource and Environmental Studies \\ The Australian National University.
}

\title{
Smallpox Eradication: Man's Success in Eliminating a Most Dangerous Disease
}

\section{Introduction}

In Egypt in the year $1160^{\circ}$ B.C., King Ramses V died of an acute disease that was characterized by a disfiguring rash. The characteristics and distribution of the rash, which can be seen on the skin of the King's mummified body preserved in the Cairo Museum, are such that scientists believe he died of smallpox. This may be the first physical evidence in the history of medicine that smallpox was present in North Africa already more than 3,000 years ago.

Severe epidemics of smallpox or smallpox-like diseases were described in many areas of Africa and Eurasia before the 15 th century. In the 16 th century, smallpox invaded the Americas, and since the 17th century it has been rampant practically throughout the world.

There had been no known effective control measures for this disease until Edward Jenner discovered a vaccine towards the end of the 18th century. This vaccine had been gradually used in many countries during the 19th century and the first half of this present century. Intensive vaccination programmes, developed during this period in North America and Europe, helped to stop indigenous spread of the disease in these areas, and thus the concept of eradication gradually emerged, based on the realization that the disease was maintained only by person-to-person transmission. Thus, would it not be possible to eliminate the disease by giving immunity to all persons through good vaccination programmes? In 1958 , the Russian delegation proposed a resolution aimed at the global eradication of smallpox to the delegations at the World Health Assembly, who wholeheartedly adopted such a resolution. However, progress thereafter was slow because health services in the zones of endemic smallpox had only limited resources and were unable to develop systematic vaccination programmes.

In 1967, an intensified global programme for the eradication of smallpox was started on the basis of another resolution that had been passed at the session of the World Health Assembly which had been held in 1966. This identified the difficulties in programme development due to unavailability of adequate resources in zones with endemic smallpox, and decided that the global programme should receive funding from the WHO budget as well as voluntary contributions from developed countries.

For the strategy and development of the programme, there were a few important advances that were identified. during the campaign as outlined in the next three numbered sections:

\section{1) Improvement of Vaccine Quality}

When the intensified global campaign was organized in 1967, the World Health Organization (WHO) carried out an extensive survey to discover whether the vaccine that was being used in the countries with endemic smallpox really met WHO standards. Surprisingly, the results showed that only $15 \%$ of the vaccine batches met WHO standards. This implied that some $85 \%$ of the vaccinations that were being administered during the eradication campaign throughout the world, were giving incomplete protection. Urgent action had therefore to be taken.

Vaccine samples from all the producers that were supplying vaccine to the eradication campaign were henceforth subject to WHO testing, and only batches of good quality were used. Intensive consultative work commenced between international experts and producers in order to improve the method of production, following which a simple and practical manual of the production methodology of the vaccine was made available to the producers by WHO.

By $1970,80 \%$ of the vaccine met WHO standards and, by $1973,95 \%$. This improvement in the quality of the vaccine was the first important contribution to the successful development of the programme.

\section{2) From Mass Vaccination to the Surveillance-contain- ment Method}

At the beginning of the campaign, systematic coverage of the population by effective smallpox vaccination was considered to be the essential method for ultimate eradication. However, after two years of the campaign, it was recognized that this method was unrealistic and ineffective, and for several reasons. First, $100 \%$ vaccination coverage was a very difficult task to achieve in the areas where the functioning of the health services was extremely poor, though it was chiefly in these areas that smallpox was continuing. Secondly, even if $80-90 \%$ of the population was vaccinated, with great effort, the remaining non-immunized $10-20 \%$ of the population was sufficient to maintain smallpox transmission-particularly if the areas were densely populated. On the other hand, epidemiological investigation of smallpox outbreaks showed that smallpox cases were now usually occurring only in a limited number of villages, and that the spread of the disease was much slower than had previously been believed.

Now the following question arose: the effective and economical way to stop transmission would be to identify the villages where cases were occurring and, instead of carrying out mass vaccination campaigns on a large scale, conduct quick and small-scale vaccination programmes to contain the outbreaks in, for example, a particular village. In fact this method, termed the 'surveillancecontainment method', proved to be more effective than mass-vaccination programmes in interrupting transmission 
of smallpox in West and Central Africa during 1967 to 1969. The method was rapidly adapted for the eradication programmes in other regions, such as South America and the Indian sub-continent.

Despite the important work of MacCallum \& McDonald (1957), a recent study on the effect of temperature and relative humidity on variola (smallpox) virus in crusts (scabs) collected from patients, indicated that the virus remains viable in crusts for only a few months in a tropical climate (Huq, 1976). More important, however, are the epidemiological findings in many countries in different parts of the world, namely that smallpox has long been eradicated from them and that there has been no spontaneous recurrence in them unless it was known that the disease had been imported by the patient from one of the remaining areas of endemic smallpox. As well as North America and Europe, such areas include Madagascar (which has been free from smallpox since 1935), Philippines (free since 1950), Greece (free since 1951), Thailand (free since 1963), and Ecuador (free since 1965).

\section{3) Mobilization of World Resources}

Member States of WHO recognized the urgency and desirability of completing eradication as soon as possible. Accordingly international collaboration between smallpox-endemic and fund-giving countries developed, in addition to the WHO regular budget - thus promoting cash donations, the participation of international epidemiologists, and engendering free supplies of the vaccine. Forty-six countries, as well as UNEO, UNICEF, UNDRO, and a few private organizations, contributed to the WHO Voluntary Fund for Smallpox Eradication or helped on a bilateral basis, and these donations have totalled US $\$ 111$ millions during the last 13 years. More than 700 epidemiologists from 70 countries participated in the programme as international personnel.

\section{Achievement}

When the intensified global programme was started in 1967, there were 33 smallpox endemic countries, includ. ing Brazil in South America, countries in Africa south of the Sahara, and others in South-East Asia (including Indonesia). Brazil recorded its last case in 1970 and Indonesia in 1971. South-East Asia, which included the smallpox-endemic countries of Bangladesh, India, and Pakistan, recorded its last cases in 1975, and the last case in the world occurred in Somalia in October 1977.

Surveillance continued to check 'entire populations' by house-to-house visits which were carried out at regular intervals during at least two years after the national eradication campaigns reported the occurrence of the last cases in their countries. These procedures verified that smallpox transmission had in fact been stopped.

\section{Benefit-cost Analysis}

The achievement of eradication means that smallpox vaccination certificates for international travellers, and routine smallpox vaccination programmes, are no longer necessary. In fact, currently 78 countries have stopped smallpox vaccination programmes and the number is expected to increase rapidly. All nations have abolished the requirement for an international certificate of smallpox vaccination from travellers, except in four instances -Chad, Democratic Kampuchea, Djibouti, and Madagascar - which still maintain the requirement.

A total of US $\$ 313$ millions (US $\$ 113$ millions from WHO and sources of international assistance, and roughly US $\$ 200$ millions from the endemic-smallpox countries themselves) was spent during the last 13 years of the campaign. The savings resulting from the termination of the vaccination programmes are estimated to be US\$1000 millions per year. Thus an equivalent of three months' expenditure should have ensured the elimination of this dread scourge of humanity for all time!

\section{Post-eradication policy}

To maintain the permanent status of eradication, a post eradication policy has been established and is being implemented. Two hundred million doses of vaccine will be reserved in case of an unexpected emergency.* Epidemiological surveillance of suspected cases of smallpox, and research activities on poxviruses (the group to which the smallpox virus belongs), are continuing. The smallpox virus is now confined in test tubes in only six laboratories under strict security and constant surveillance.

Isao Arita, Chief
Smallpox Eradication Unit
World Health Organization
Avenue Appia
1211 Geneva 27
Switzerland.

\section{REFERENCES}

HUQ, Farida (1976). Effect of temperature and relative humidity on variola virus in crusts. Bull. Wld Hlth Org., 54(6), pp. $710-2$

MacCALLUM, F. O. \& McDONALD, J. R. (1957). Survival of variola virus in raw cotton. Bull. Wld Hlth Org., 16(2), pp. 247-54.

\footnotetext{
*Including the abhorrent conceivability of 'Deliberate release' as a biological weapon in warfare or "by an individual or group as an act of sabotage or terrorism', though 'unless the public health services had completely broken down, the outbreak that followed could be readily contained and the virus then eliminated' (The Achievement of Global Eradication of Smallpox: Final Report of the Global Commission for the Certification of Smallpox Eradication. World Health Organization, Geneva, Switzerland, WHO/SE/79.152, 122 pp., illustr. (mimeogr.).—Ed.
}

\section{Major Conservation Research Centre for China}

China and the World Wildlife Fund (WWF) have announced plans for a multi-million dollar, jointlyfinanced major conservation research centre to be built in the highlands of Sichuan (Szechwan) Province in southwestern China. Located in one of the main breeding. grounds of the Giant Panda (Ailuropoda melanoleuca), in the 200,000-hectares Wolong Nature Reserve, the centre will concentrate initially on research on the endangered Giant Panda and its life-support system, which faces a major potential threat within the next decade. At a later date, the centre will expand its research to other species of animals and plants.

Plans for the centre, which represents a cooperation with foreign specialists that in some ways is probably 